\title{
Yngre elevers uppfattningar av det matematiska i algebraiska uttryck
}

\author{
Sanna Wettergren ${ }^{1}$, Inger Eriksson ${ }^{2}$ och Torbjörn Tambour ${ }^{3}$ \\ ${ }^{1}$ Fakulteten för pedagogik och välfärdsstudier, Åbo Akademi, Vasa, Finland \\ ${ }^{2}$ Institution för de humanistiska och samhällsvetenskapliga ämnenas didaktik, \\ Stockholms universitet, Sverige \\ ${ }^{3}$ Matematiska institutionen, Stockholms universitet, Sverige
}

Det övergripande syftet med denna artikel är att analysera och beskriva yngre elevers uppfattningar av det matematiska i ett algebraiskt uttryck och utifrån det diskutera vad som kan utgöra kritiska aspekter för utvecklandet av mera kvalificerade uppfattningar. Artikeln bygger på data från ett forskningsprojekt där elever i förskoleklass, årskurs 1 och årskurs 4 intervjuades med syfte att analysera de aktuella elevernas kvalitativt skilda sätt att uppfatta det matematiska i algebraiska uttryck. Intervjuerna analyserades fenomenografiskt. Studiens resultat visar tre kvalitativt skilda kategorier av yngre elevers uppfattningar av det matematiska i algebraiska uttryck. Det matematiska i ett algebraiskt uttryck erfars som "något som kan och bör räknas ut", "något som beskriver en relation mellan komponenter" och "något som representerar en situation". Vidare identifierades tre kritiska aspekter i relation till kategorierna. De kritiska aspekter som ger eleverna möjlighet att kvalificera sina uppfattningar för att utveckla ett mer komplext kunnande av algebraiska uttryck är att kunna urskilja att 1) ett uttryck består av olika komponenter som har olika funktioner, 2 ) en och samma variabel $i$ ett uttryck har samma värde och 3) värdet på en variabel i ett uttryck bestäms relationellt. Att urskilja sådana kritiska aspekter kan hjälpa eleverna att kvalificera sitt kunnande. Således måste de kritiska aspekterna beaktas vid utformningen av undervisningen.

\author{
Artikel \\ LUMAT General Issue \\ Vol 9 No 1 (2021), 1-28 \\ Mottagen 19 juni 2020 \\ Accepterad 14 december 2020 \\ Publicerad 13 januari 2021 \\ Uppdaterad 16 juni 2021 \\ Sidor: 28 \\ Referenser: 84 \\ Kontakt: \\ sanna.wettergren@gmail.com \\ https://doi.org/10.31129/ \\ LUMAT.9.1.1377
}

Nyckelord: algebraiska uttryck, algebraiskt tänkande, fenomenografiska uppfattningar, kritiska aspekter, tidiga skolår

\section{Younger students' conceptions of the mathematics in algebraic expressions}

The overall purpose of this article is to analyze and describe younger students' conceptions of or ways of experiencing the mathematics in an algebraic expression and to discuss what can be critical aspects for the development of more qualified conceptions. The article is based on data from a research project where students in preschool class, Grade 1 and Grade 4 were interviewed with the aim of analyzing the students' qualitatively different ways of experiencing the mathematics in algebraic expressions. The interviews were analyzed with phenomenography. The results show three qualitatively different categories of younger students' conceptions of the mathematics in algebraic expressions. The mathematics in an algebraic expression is experienced as "something that can and should be calculated", "something that describes a relationship between components", and 
"something that represents a situation". Furthermore, three so-called critical aspects the students need to discern were identified in relation to the categories 1) an expression consists of different components that have different functions, 2) one and the same variable in an expression has the same value and 3) the value of a variable in an expression is determined relationally. Discerning such critical aspects may help the students to qualify their ways of knowing. Thus, the critical aspects need to be considered in the design of teaching.

Keywords: algebraic expressions, algebraic thinking, critical aspects, phenomenographic conceptions, primary education

\section{Introduktion}

En förutsättning för att utveckla kunskaper inom olika områden i matematik är en förståelse av algebra (Bråting et al., 2018; Hemmi et al., 2020). Algebra ses av tradition som ett av de mer krävande matematiska innehållen i grundskolans matematikundervisning och har i västvärlden därför tidigare introducerats rätt sent, ofta först i högstadiet (se t.ex. Bråting et al., 2019; Hemmi et al., 2020; Kilhamn \& Röj-Lindberg, 2019; Stacey \& Chick, 2004). Såväl svensk som internationell forskning har de senaste decennierna fört fram argument som pekar på vikten av att introducera algebra tidigt i skolan, främst i syfte att utveckla elevers algebraiska tänkande (se t.ex. Blanton et al., 2015; Bråting et al., 2019; Cai \& Knuth, 2011; Davydov, 2008; Eriksson \& Jansson, 2017; Kieran, 2018; Mason, 2008, 2018; Schmittau, 2004, 2005). Intresset för att introducera algebra tidigt i skolan kommer bland annat till uttryck i hur läro- och kursplaner i matematik ${ }^{1}$ formulerats. I Sverige och de övriga nordiska länderna framträder likheter gällande kursplanernas centrala innehåll för algebra och när detta innehåll introduceras. I den finländska kursplanen från 2014 lyfts exempelvis att eleverna i årskurs 1-2 ska erbjudas möjligheter att utveckla sin förmåga att upptäcka likheter, skillnader och mönster (Utbildningsstyrelsen, 2020). Vidare ska de i årskurs 3-6 introduceras till begreppet obekant samt ges möjlighet att undersöka ekvationer. Liknande innehåll lyfts i den svenska (Skolverket, 2019), den danska från 2019 (Undervisningsministeriet, 2020) och den norska kursplanen (Utdanningsdirektoratet, 2020). Gemensamt för kursplanerna är att eleverna inledningsvis introduceras till ämnesinnehållet tal och mönster, i form av mönster i talföljder och talföljder utifrån en regel. I årskurserna 4-6 introduceras variabler och

\footnotetext{
${ }^{1}$ De nordiska läro- och kursplanerna använder olika begreppsapparater för likartade områden. Exempelvis används läro- och kursplaner samt kompetenser, mål och förmågor synonymt. I artikeln används de svenska benämningarna för motsvarande områden.
} 
ekvationer där även likhetstecknets betydelse behandlas. ${ }^{2}$ I Sverige betonas likhetstecknets betydelse tydligare jämfört med de andra länderna. Detta framträder exempelvis i en studie om svenska läromedel för de yngsta eleverna i form av uppgifter där värdet på ett okänt tal efterfrågas $4+\ldots=8$ (Hemmi et al., 2019). Denna typ av uppgifter återkommer även i läromedel för årskurs 7-9.

Utifrån forskning om algebraundervisning (utvecklas nedan) vet vi att elever vanligen introduceras till algebra på en aritmetisk grund i form av exempelvis uppgifter riktat mot likheter där värdet på ett okänt tal efterfrågas. Samtidigt argumenterar allt fler forskare för att elever snarare behöver möta uppgifter och situationer som utvecklar ett algebraiskt tänkande. Exempelvis behöver elever få en möjlighet att utforska algebraiska strukturer (Blanton et al., 2015; Bråting et al., 2018; Kieran et al., 2016). Hur elever uppfattar algebraiska fenomen i form av det generella (symboler, strukturer och relationer) i algebraiska uttryck eller ekvationer fokuseras dock inte i särskilt många studier (se t.ex. Bråting et al., 2019).

\subsection{Syfte och frågeställningar}

Syftet med föreliggande artikel är att med hjälp av en fenomenografisk analys beskriva och diskutera yngre elevers erfarande av det matematiska i algebraiska uttryck. Med ett algebraiskt uttryck avses i denna artikel en meningsfull sammansättning av matematiska symboler (Kiselman \& Mouwitz, 2008). Det innebär exempelvis att $a+$ $b-\operatorname{coch} a x+b$ är uttryck, men även olikheten $a<b$ och likheten (eller ekvationen) $a=b+c$ (James \& James, 1976). I studien som ligger till grund för denna artikel har vi använt algebraiska uttryck i form av likheter av typen $5 x=y$. Vidare är syftet att identifiera potentiella kritiska aspekter i relation till mer kvalificerade uppfattningar av algebraiska uttryck. Syftet preciseras i följande två frågeställningar:

- Vilka kvalitativt skilda sätt att erfara algebraiska uttryck kan urskiljas?

- Vilka aspekter behöver eleverna erfara för att de ska ges möjlighet att kvalificera sina uppfattningar om algebraiska uttryck?

\footnotetext{
${ }^{2}$ I den reviderade svenska kursplanen i matematik som träder i kraft 1 juli 2021 introduceras obekanta tal och hur de kan symboliseras redan $i$ årskurs $1-3$ och variabler och användningen av variabler i exempelvis enkla algebraiska uttryck och ekvationer samt algebraiska metoder för att lösa enkla ekvationer introduceras redan i årskurs 4-6 (Skolverket, 2020).
} 


\title{
2 Tidigare forskning om algebraundervisning
}

Även om algebra idag introduceras redan i grundskolans lägsta årskurser är det vanligast att det sker i vad van Oers (2001) benämner som en aritmetisk undervisningstradition, i form av det som kan beskrivas som pre-algebra (se t.ex. Gravemeijer, 2002; Kaput et al., 2008; Kieran, 2006; Lins \& Kaput, 2004; Riesbeck, 2008; Schmittau, 2004, 2005). Med ett aritmetiskt tänkande som grund kan elever få svårt att föra ett mer generellt analytiskt resonemang om till exempel vad en variabel representerar eller hur man kan förstå ett okänt värde (Schmittau, 2004, 2005). Stacey och MacGregor (1999) betonar att när elever i senare årskurser introduceras till algebra, exempelvis i form av ekvationer, tenderar de att försöka lösa dessa med en aritmetisk problemlösningsmetod genom att lägga in bestämda värden för att på detta sätt kunna argumentera för en lösning.

Krutetskii (1976) beskriver de problem många elever har när de möter algebra på följande sätt:

\begin{abstract}
It was always very hard for our students to abstract themselves from concrete numerical expressions. Our students had difficulty (some more, others less, but all had difficulty!) understanding the very essence of algebra, which is an operation with numerical abstractions. It was hard for them to understand that letters in algebra are numbers deprived of their concrete expression. (Krutetskii, 1976, s. 253-254)
\end{abstract}

Krutetskii menar alltså att svårigheten för eleverna är förståelsen för att själva kärnan i algebra är operationer med numeriska abstraktioner, det vill säga att bokstäver i algebra är okända kvantiteter eller värden.

\subsection{Tidig introduktion av algebra}

För att motverka en del av de svårigheter som brukar uppstå senare i utbildningen förespråkas inom forskningsfältet early algebra att elever med fördel kan introduceras till algebraisk problemlösning och algebraiskt tänkande tidigt (Blanton et al., 2018; Blanton et al., 2015; Bråting et al., 2019; Cai \& Knuth, 2011; Eriksson \& Jansson, 2017; Kieran, 2018; Kieran et al., 2016; Mason, 2008; Radford, 2015). Vad som menas med termen "tidigt" skiljer sig dock åt. Länge har "tidigt" refererats till elever som är 10-12 år gamla medan det idag är vanligare att använda termen "tidigt" i relation till algebra för elever i förskoleklass eller årskurs 1 (Blanton et al., 2015; Kieran, 2011; Morris \& Sloutsky, 1995). 
Enligt Blanton et al. (2015) anger Kaput (2008) två grundläggande handlingar för att beskriva ett algebraiskt tänkande: (i) att uttrycka generaliseringar i allt högre grad med formella och konventionella symbolsystem; och (ii) att föra och följa resonemang med symboler. Utveckling av algebraiskt tänkande inbegriper bland annat utforskandet av generella, grundläggande och teoretiska samband och strukturer (Blanton et al., 2015; Davydov, 2008; Kaput, 2008; Venenciano \& Dougherty, 2014). Ett flertal forskare hänvisar idag till det matematiska program som utvecklats av El'konin och Davydov som en framgångsrik modell för tidig introduktion av algebra (se t.ex. Cai \& Knuth, 2011; Kieran et al., 2016; Schmittau, 2004, 2005; Venenciano \& Dougherty, 2014). Davydov (1990) beskriver detta som "ascending from the abstract to the concrete" (s. 173) och menar att elever, genom lärandemodeller och kollektiva reflektioner, först behöver lära sig att arbeta med generella strukturer och relationer i exempelvis algebraiska uttryck, för att senare använda dem i konkreta numeriska operationer. Kieran (2004) föreslår också att elever tidigt på olika sätt behöver arbeta teoretiskt med algebra.

\begin{abstract}
Algebraic thinking in the early grades involves the development of ways of thinking within activities for which the letter-symbolic algebra could be used as a tool, or alternatively within activities that could be engaged in without using the letter-symbolic algebra at all, for example, analyzing relationships among quantities, noticing structure /.../ generalizing, problem solving. (Kieran, 2004, S. 149)
\end{abstract}

Algebraiskt tänkande kan enligt Kieran alltså handla om användning av bokstavssymboler vid analys av exempelvis relationer mellan kvantiteter, strukturer och generalisering. Schmittau och Morris (2004) hävdar att en tidig algebraundervisning lägger grunden för ett pre-numeriskt tänkande (att lära sig att förstå olika tal som tal), i motsats till ett pre-algebraiskt tänkande som dominerar i aritmetiska undervisningstraditioner. Schmittau och Morris jämför den undervisning som Davydov och hans kollegor i Ryssland utvecklat med motsvarande undervisning i USA: "Thus, while children in the US have pre-algebraic experiences that are numerical, Russian children studying Davydov's curriculum have pre-numerical experiences that are algebraic" (s. 61, emfas i original). Davydov (1975) benämner en sådan undervisning som "algebraization of elementary mathematics" (s. 202). Idén med en pre-numerisk förståelse är att eleverna behöver utveckla en teoretisk grund för att förstå olika tal som tal och att inte se tal i exempelvis uttryck enbart som diskreta storheter, som heltal (Eriksson, 2015). Mot denna bakgrund behöver en undervisning som skapar förutsättningar för elever att utveckla förmågor som att 
resonera algebraiskt, att göra algebraiska generaliseringar samt att använda algebraiska representationer erbjudas elever (Greer, 2008; Kaput, 1999; Usiskin, 1988). För att ha en grund för undervisningens utformning behöver vi även kunskaper om hur elever uppfattar olika matematiska fenomen, som exempelvis algebraiska uttryck.

\subsection{Uppfattningar av algebraiska fenomen}

I en systematisk litteratursökning3 framkommer det att forskningen gällande uppfattningar av fenomen kopplat till algebra är begränsad. En större del av studierna undersöker äldre elevers, lärarstudenters eller lärares föreställningar, uppfattningar eller missuppfattningar gällande algebra. Ett fåtal studier fokuserar yngre elevers uppfattningar och ännu färre studier har använt en fenomenografisk ansats. I det följande har vi begränsat oss till studier som berör algebraiska fenomen som uttryck, ekvationer och likhetstecken. Ett flertal studier som till exempel berör mönster, funktioner och substitution har sorterats bort.

Även om vår studie direkt intresserar sig för de yngsta elevernas uppfattningar av algebraiska uttryck har studier som riktar sig mot äldre elevers och lärares uppfattningar relevans för föreliggande artikel. Av de studier vi granskat finns uppfattningar som är av olika karaktär. Exempelvis framkommer det i en del av studierna att elever har uppfattningar som inte är av matematisk karaktär (tolkar bokstäver alfabetiskt eller som en förkortning) men även uppfattningar av att algebraiska uttryck implicerar numeriska operationer (Knuth et al., 2005; MacGregor \& Stacey, 1997; Sfard \& Linchevski, 1994; Stacey \& MacGregor, 1997; Wagner, 1983). Stacey och MacGregor exemplifierar hur elever tar med sig vardagserfarenheter in i algebraundervisningen. Det kan till exempel inkludera elevers användningar av bokstäver i andra sammanhang, operationer med sammansatta symboler (t.ex. 7 1/2, 34 , XII) och att läsa likhetstecknet som ett processtecken, det vill säga att något "blir". I studier som har undersökt elevers uppfattningar av likhetstecknet erfars uttrycket till vänster om likhetstecknet som en process och uttrycket till höger som resultatet (Frieman \& Lee, 2004). Detta innebär att likhetstecknet signalerar att något ska "ska göras”, det vill säga som ett processtecken (Kieran, 1981). Knuth et al. (2005) visar även på en förståelse av likhetstecknet som betecknande en relation, det vill säga att

\footnotetext{
${ }^{3}$ Huvudsökning gjordes i databasen Ebsco där sökorden conception, perception, misconception, beliefs, phenomenography, phenomenographic tillsammans med algebraic användes i olika kombinationer. Sökningar har också gjorts i SWEpub med motsvarande söktermer på svenska. Även kedjesökning utifrån från tidigare kända studier och de studier som identifierades i den systematiska sökningen har använts.
} 
man skapar en likhet mellan de två sidorna av en given aritmetisk ekvation (Carpenter et al., 2003; Knuth et al., 2005). Ronda (2009) menar att det är centralt att elever har en förståelse av den relationella aspekten i en ekvation då detta är nästa steg för att kunna lösa uppgifter med två variabler. Att notera är att Attorps (2006) studie visar att även en del lärare erfar ekvationer som en procedur, som ett svar eller som ett uttryck.

En tidig studie som behandlar elevers uppfattningar av algebraiska bokstavssymboler, genomförd av Küchemann (1981, jfr även Wagner, 1983), beskriver sex skilda uppfattningar: 1) bokstaven tilldelas ett värde; 2) bokstaven används inte; 3) bokstaven används som objekt eller förkortning; 4) bokstaven används som ett specifikt, okänt tal; 5) bokstaven används som ett godtyckligt tal och 6) bokstaven används som variabel (för svensk översättning av Küchemanns kategorier se Olteanu, 2014). Även i Küchemanns kategorisering kan de tre första kategorierna kopplas till sådana erfarenheter som Stacey och MacGregor (1997) diskuterar. Det är således endast kategorierna 4-6 ovan som kan ses som mer matematiskt relevanta.

Ett flertal studier exemplifierar och diskuterar sådana uppfattningar som ses som outvecklade, felaktiga eller som bygger på missförstånd. Få studier tar sikte på vad elever som ser likhetstecknet som en processymbol behöver urskilja för att utveckla en mer algebraisk relevant förståelse. Forskning som använder variationsteori talar om vilka aspekter av ett kunnande som eleverna behöver lära sig - så kallade kritiska aspekter (se t.ex. Kullberg et al., 2017; Olteanu, 2007; Wernberg, 2009). Det som ännu inte urskilts är därmed det som i variationsteorin beskrivs som kritiska aspekter (Pang \& Ki, 2016).

Mot bakgrund av den tidigare forskningen som refererats ovan finns det således skäl att studera de yngsta elevernas uppfattningar av fenomen som algebraiska uttryck, det vill säga innebörden i det kunnande eleverna förväntas utveckla.

\section{Metod och analys}

Data som ligger till grund för artikeln kommer från ett treårigt forskningsprojekt, 2017-2019, finansierat av Skolforskningsinstitutet (2020), där målet var att främja elevers algebraiska resonemangsförmåga (Eriksson et al., 2019; Stockholms universitet, 2020). För att få en grund för detta forskningsprojekt genomförde vi en mindre fenomenografisk kartläggningsstudie med elever från förskoleklass, årskurs 1 
och årskurs 4. Det initiala syftet med kartläggningen var att utforska och beskriva de aktuella elevernas kvalitativt skilda sätt att uppfatta algebraiska uttryck.

Sammanlagt 20 elever intervjuades, tio elever från förskoleklass och årskurs 1 samt tio elever från årskurs 4 vid två olika skolor. 4 Eleverna intervjuades parvis där utgångspunkt för sammansättningen av elevparen var att de skulle bestå av en elev som bedömdes vara mer kunnig i matematik och en elev som bedömdes vara lite mindre kunnig. Urvalet gjordes i samråd med undervisande lärare med avsikten att skapa förutsättningar för kvalitativt skilda uppfattningar gällande algebraiska uttryck att framträda. Eleverna i förskoleklassen, årskurs 1 och de i årskurs 4 hade inte undervisats om algebra eller algebraiska uttryck innevarande läsår. Däremot hade alla elever tidigare mött uppgifter där värdet på ett okänt tal efterfrågas.

\subsection{Elevintervjuer}

Frågorna i intervjuerna konstruerades utifrån erfarenheter från en pilotstudie där eleverna arbetat med Cuisenairestavar 5 för att utforska relationella aspekter i algebraiska uttryck. Utgångspunkten var att intervjufrågorna skulle öppna upp för elevers erfarande av olika aspekter av strukturer och relationer. Vi utgick även från variationsteoretiska principer i utformningen av de konkreta exemplen som utgjorde underlag för frågorna. Intervjuerna kan således beskrivas som materialbaserade (se t.ex. Lindberg \& Löfgren, 2010). En idé med materialbaserade intervjuer, som här är genomförda med hjälp av olika visuella representationer, är att i någon mån kunna säkerställa vilket fenomen som adresseras (Adawi et al., 2001; Ingerman et al., 2009; Jägerskog, 2020). Samtidigt innebär detta givetvis också en begränsning i vad intervjupersonerna kommer att tala om. Med små barn är det speciellt svårt att genomföra intervjuer så att det valda fenomenet kan hållas i fokus (Jaidin, 2018; Österlind, 1998). Som nämnts hade eleverna inte mött denna typ av algebraiska uttryck tidigare varför vi har utgått ifrån att den riggade intervjusituationen hjälpt till att hålla fenomenet "algebraiska uttryck" i fokus. Frågorna utformades utifrån en idé om att eleverna skulle resonera om hur andra elever kunde ha tänkt när de löste uppgifterna med intentionen att detta också skulle öka förutsättningarna med att hålla fokus på fenomenet.

\footnotetext{
${ }^{4}$ Eleverna som intervjuades i förskoleklass och årskurs 4 skulle delta i forskningslektionerna följande termin.

${ }^{5}$ Cuisenairestavar är ett slags relationellt laborativt material som består av stavar i olika längder och färger, där varje längd har en viss färg (Küchemann, 2019) (se Figur 1).
} 


\subsection{Intervjufrågorna}

Intervjufrågorna kombinerades, som nämnts ovan, med material i form av bilder på skrivna algebraiska uttryck såsom $5 x=y, 5^{c}=z$ och $k=3 e$ samt bilder där de algebraiska uttrycken gestaltades med hjälp av Cuisenairestavar (se Figur 1).

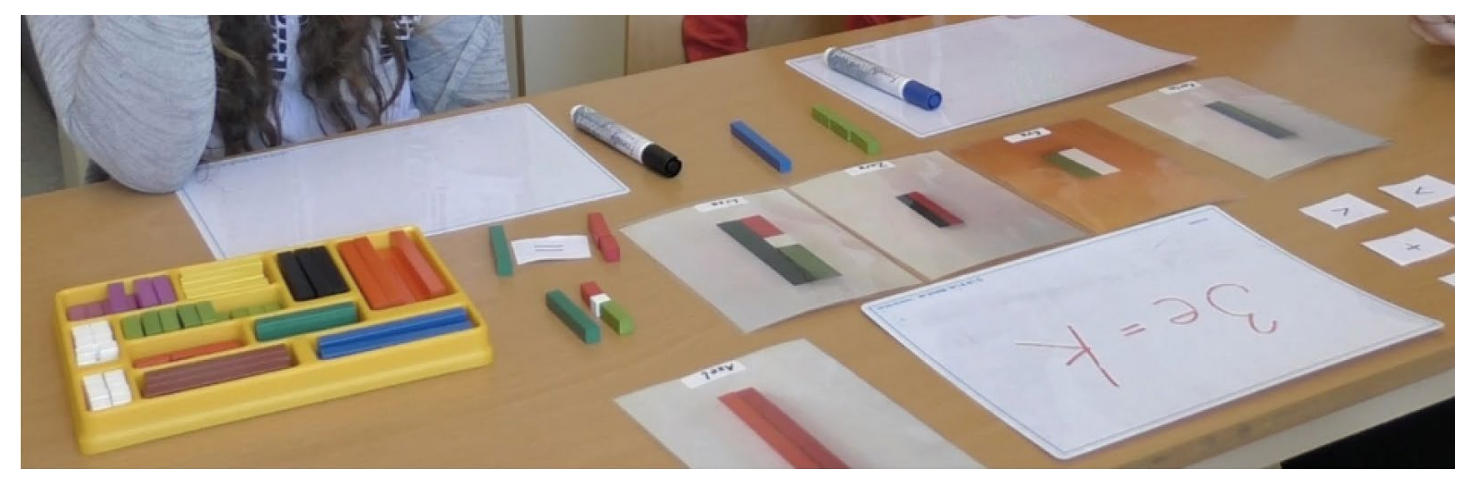

Figur 1. Materiell iscensättning av intervjusituationen under elevintervjuerna.

Även Cuisenairestavar i fysisk form fanns tillgängliga för eleverna. Vidare hade eleverna tillgång till små whiteboards med tillhörande whiteboardpennor. Samma intervjufrågor användes vid intervjuerna med samtliga elever, det vill säga i förskoleklass, årskurs 1 och årskurs 4. Vi ställde inga direkta frågor riktade till fenomenet. Vi frågade således inte eleverna "Vad är ett uttryck?”, utan genom att eleverna fick arbeta med de algebraiska uttryck som var avbildade framträdde vad och vilka aspekter eleverna innehållsligt fokuserade.

Ingångsfrågan i intervjuerna var att vi sa att elever "i en annan klass" hade fått se ett algebraiskt uttryck, $5^{x}=y$, och att eleverna "i den andra klassen" fick i uppgift att visualisera uttrycket genom att använda Cuisenairestavar: "... i den klassen fick de [eleverna] en uppgift /.../ de skulle visa eller lägga det här uttrycket: fem x är lika med $\mathrm{y}[5 x=y]$ ”. Efter ingångsfrågan visade vi en bild på en stavkonstruktion med en orange stav med fem röda stavar bredvid (Figur 2) och la med fysiska Cuisenairestavar en likadan stavkonstruktion som bilden på Axels konstruktion. Sedan frågade vi hur den eleven som hade lagt stavarna så kunde ha tänkt: "Axel la uttrycket så här. Hur kan Axel ha tänkt och resonerat när han gjorde det?”. 


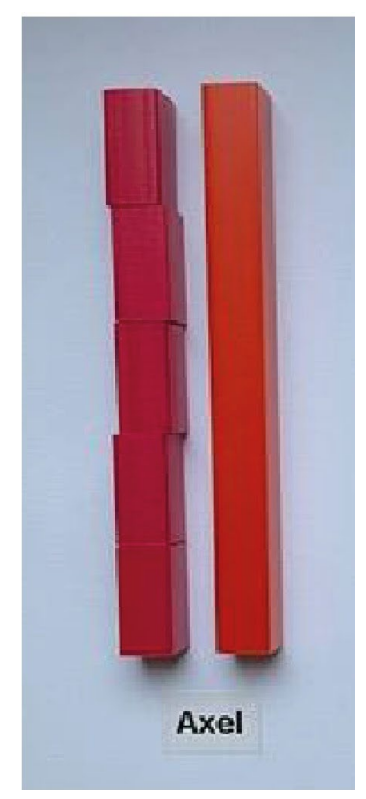

Figur 2. Axels stavkonstruktion i relation till uttrycket $5 \mathrm{x}=\mathrm{y}$.

I den andra intervjufrågan använde vi en bild på en annan stavkonstruktion som också illustrerade uttrycket $5 x=y$ (Figur 3). Uttrycket hölls således konstant medan stavkonstruktionen varierades. Vi sa: "Lovisa la uttrycket så här” och frågade därefter ”Hur kan hon ha tänkt? Kan man göra så?”

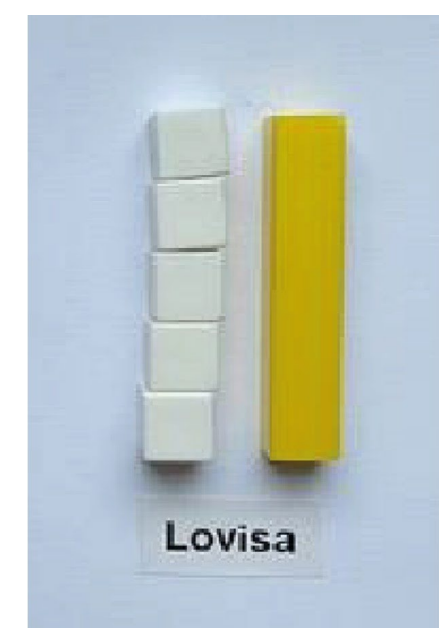

Figur 3. Lovisas stavkonstruktion i relation till uttrycket $5 \mathrm{x}=\mathrm{y}$.

I fråga tre valde vi att hålla en stavkonstruktion konstant och variera uttrycket. Vi visade Axels stavkonstruktion (Figur 2 ovan) och sa: "Pelle, en elev i en annan klass, fick se Axels stavkonstruktion och Pelle fick i uppgift att skriva ett uttryck till den. Han skrev uttrycket fem $\mathrm{c}$ är lika med $\mathrm{z}$ [intervjuaren skrev samtidigt $5 \mathrm{c}=\mathrm{z}$ på en liten whiteboard]. Hur kan han ha tänkt när han skrev det?” 
Den fjärde och sista frågan inleddes med att vi visade tre bilder på olika stavkonstruktioner som förslag till samma uttryck, $k=3 e$, och frågade hur de tre fiktiva eleverna, Karim, Zara och Lisa, kunde ha tänkt när de la sina olika stavkonstruktioner med Cuisenairestavar (Figur 4). De tre stavkonstruktionerna stämde relationellt med varandra men endast två av konstruktionerna stämde med uttrycket $k=3 e$.

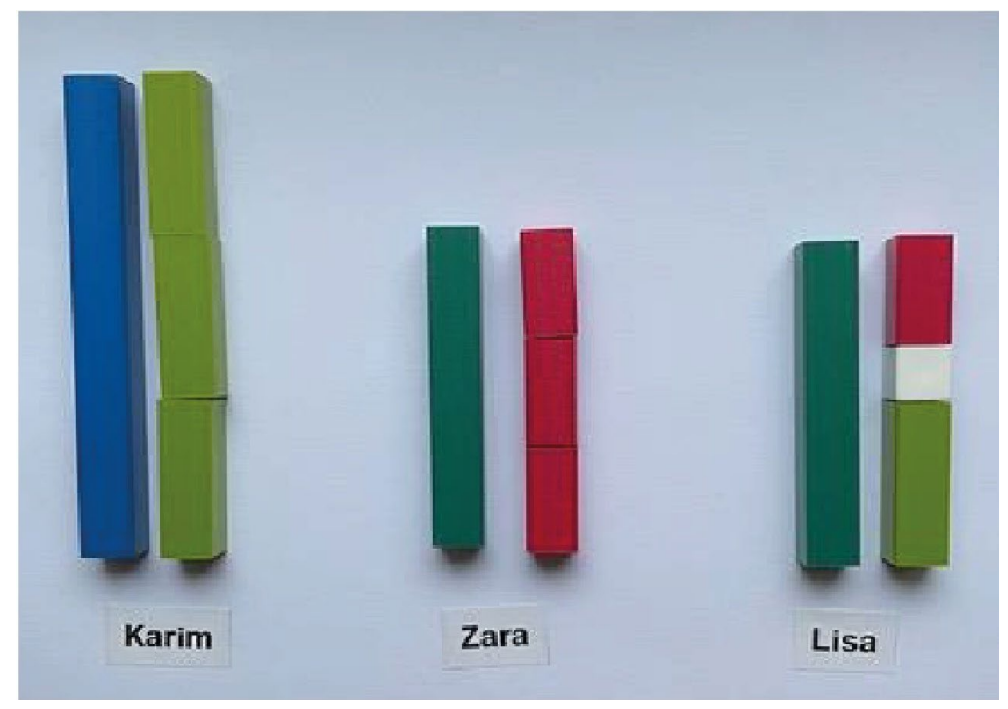

Figur 4. Karims, Zaras och Lisas stavkonstruktioner i relation till uttrycket $\mathrm{k}=3 \mathrm{e}$.

Samtliga intervjuer videofilmades och transkriberades i sin helhet utifrån Linells (1994) beskrivning: ordagrant, talspråkligt neutralt samt organiserat i replikform. Även gester och referenser till materialet som eleverna hade tillgång till har beskrivits i hakparenteser (Nordin \& Boistrup, 2018). Vid transkriberingen har elevernas namn fingerats.

\subsection{Fenomenografisk analys}

Elevintervjuerna analyserades fenomenografiskt (Marton, 1981). En fenomenografisk analys syftar till att förstå och beskriva kvalitativt skilda sätt att uppfatta eller erfara ett fenomen. Ett grundantagande är att människor, på basis av vad de har erfarit i livet, vilka situationer och problem de har mött, uppfattar ett fenomen på ett specifikt sätt, det vill säga att vi urskiljer olika aspekter ofta mer eller mindre komplexa sådana (Marton, 1981; jfr Eriksson, 1999). Inom fenomenografi skiljer man på första och andra ordningens perspektiv, där första ordningens perspektiv handlar om vad en person framför som sant eller värderar. Andra ordningens perspektiv, vilket är 
fenomenografins intresse, handlar istället om vad personerna erfarit och som därmed ligger till grund för hur de uttalar sig. Enkelt uttryckt handlar första ordningens perspektiv om det som står på raderna i en transkriberad intervju medan andra ordningens perspektiv handlar om det underförstådda, det som ligger bakom eller bortom raderna (Marton, 1981; Pang, 2003). Bland personer verksamma inom en och samma praktik, exempelvis matematiklärare, förskoleklasselever eller årskurs fyraelever är det ovanligt att det förekommer en mycket stor variation av uppfattningar. Detta innebär att fenomenografin inte intresserar sig för en enskild persons uppfattningar, utan istället antas en och samma person kunna ge uttryck för en eller flera uppfattningar. En fenomenografisk analys resulterar således vanligen i ett begränsat antal, men kvalitativt skilda, uppfattningar (Marton, 1981, 2015, jfr även Eriksson, 1999) Analysarbetet med att identifiera de olika uppfattningarna förutsätter att både kunna fokusera vad de intervjuade talar om (fenomenet) och hur de talar om det. Resultatet från en fenomenografisk analys utgörs av ett antal kvalitativt skilda uppfattningar presenterade som sinsemellan relaterade kategorier. Sammantaget utgör kategorierna med deras inbördes relationer ett utfallsrum. Det innebär att det som kvalitativt skiljer en uppfattning från en annan är begripligt först när de relateras till varandra (Marton, 1981). Kategorierna i utfallsrummet följer vanligen en hierarkisk logik.

Variationsteorin kan ses som en vidareutveckling av fenomenografin. Den använder resultatet från en fenomenografisk analys för att urskilja så kallade kritiska aspekter. Detta innebär att en hierarkisk ordning på kategorierna implicerar ett mer differentierat urskiljande av olika aspekter. För att arbeta fram kritiska aspekter analyseras kategorierna i relation till varandra för att identifiera aspekter som är urskilda i respektive kategori och i förlängningen vilka aspekter som behöver urskiljas för utvecklingen av en allt mer differentierad uppfattning.

\subsection{Vågen fram till kategorier}

Inledningsvis närlästes de transkriberade elevintervjuerna flera gånger med fokus på att identifiera vad eleverna talade om. Intervjumaterialet visade indikationer på utsagor som antydde att uttrycken eleverna presenterades för bland annat uppfattades som en gåta, en kluring, alfabetisk logik, att versaler och gemener hade betydelse eller att bokstäverna kunde vara en förkortning. Eftersom det matematiska innehållet algebra, här i form av algebraiska uttryck, var nytt för eleverna var det också vanligt att eleverna inledningsvis gissade och kopplade till vardagserfarenheter 
(jfr MacGregor \& Stacey, 1997; Stacey \& MacGregor, 1997). I en fenomenografisk mening utgör dessa icke-matematiskt relaterade uppfattningar också uppfattningar av fenomenet i fråga, men för forskningsprojektets behov var denna typ av uppfattningar inte relevanta. De delar som inte innefattade matematiska aspekter lades därför åt sidan. Detta innebar att fenomenet preciserades från att inledningsvis ha beskrivits som elevers uppfattningar av algebraiska uttryck till elevers uppfattningar av det matematiska $i$ algebraiska uttryck. Efter att denna avgränsning av data hade genomförts analyserades den kvarvarande sammantagna texten med elevutsagor för att genom en komparativ och simultan läsning få fram uppfattningar. Utifrån denna läsning utarbetades kvalitativt skilda kategorier som prövades mot den totala mängden elevutsagorna i materialet. När alla utsagor, eller delar av en utsaga, kunde relateras till någon av de identifierade kategorierna gjordes en beskrivning av respektive kategori.

De lärare som deltog forskningsprojektet men inte inledningsvis i analysarbetet fick i validerande syfte i uppdrag att sortera elevutsagorna i de olika kategorierna. ${ }^{6}$ De utsagor som det inte rådde samstämmighet kring granskades åter av forskargruppen7 och kategorierna justerades ytterligare. Kategorierna bearbetades och kalibrerades således i flera steg. Analysarbetet kan med andra ord beskrivas med det Wahlström et al. (1997) kallar för förhandlad samstämmighet (negotiated consensus).

Efter valideringsarbetet utformades de slutliga kategorierna med kategoribeskrivningarna och tillhörande exempel på utsagor. Sammantaget består utfallsrummet av följande tre kategorier: "något som kan och bör räknas ut", "något som beskriver en relation mellan komponenter" och "något som representerar en situation”.

\subsection{Från kategorier av uppfattningar till kritiska aspekter}

Utfallsrummet med sina tre kategorier analyserades därefter i ett nästa steg i syfte att fånga de aspekter som skilde de olika sätten att uppfatta det matematiska i algebraiska uttryck från varandra. Dessa aspekter utgör således de aspekter som är kritiska för att eleverna ska kunna utveckla ett mer kvalificerat sätt att erfara fenomenet på. Tre

\footnotetext{
${ }^{6}$ I ett första skede prövade och justerade lärarna i årskurs 1 och 5, och i ett andra skede lärarna i årskurs 6-9 och gymnasieskolan.

${ }^{7}$ I forskningsgruppen ingår Inger Eriksson, Roger Fermsjö, Jenny Fred, Verner Gerholm, Anna-Karin Nordin, Martin Nyman, Torbjörn Tambour och Sanna Wettergren.
} 
kritiska aspekter identifierades som eleverna behöver kunna urskilja (Pang, 2003; Pang \& Ki, 2016; Runesson, 2011, 2017). I nästa avsnitt presenteras det fenomenografiska utfallsrummet med sina tre kategorier samt de tre kritiska aspekter som identifierades.

\section{Resultat}

I det följande avsnittet presenteras resultatet i två delar. I den första delen presenteras de fenomenografiska uppfattningarna i form av ett utfallsrum. I den andra delen presenteras de kritiska aspekter som vi identifierat i relation till de olika kategorierna och som elever behöver ges möjlighet att urskilja för att utveckla ett mera kvalificerat kunnande av vad som kan vara det matematiska i algebraiska uttryck.

\subsection{Elevers erfarande av det matematiska i algebraiska uttryck}

Utifrån det preciserade fenomenet resulterade analysen av elevintervjuerna i tre kvalitativt skilda kategorier av yngre elevers uppfattningar av det matematiska i algebraiska uttryck. De identifierade kategorierna kan organiseras hierarkiskt och bildar tillsammans det illustrerade utfallsrummet i Figur 5 nedan. Kategorin "något som kan och bör räknas ut” kan förstås som enklare i relation till de andra två kategorierna som representerar mera komplexa uppfattningar. I de två mera komplexa uppfattningarna av fenomenet urskiljer eleverna fler aspekter.

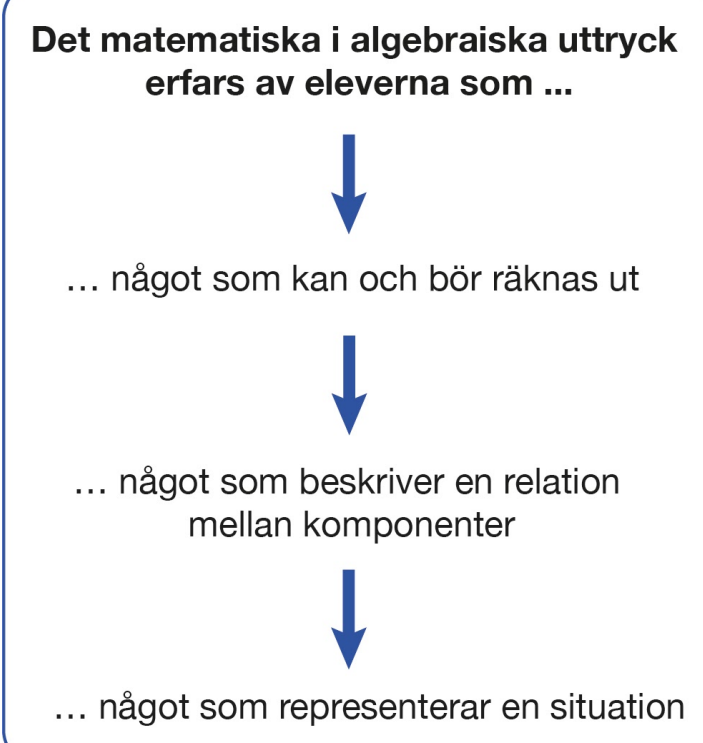

Figur 5. Schematisk bild över utfallsrummet med sina tre kategorier. 
I det följande presenteras kategorierna och exemplifieras med excerpt från förskoleklass, årskurs 1 och årskurs 4.

\subsubsection{Kategori 1: ... något som kan och bör räknas ut}

I den här kategorin uppfattar eleverna uttrycket som att det innehåller en uppmaning till dem att göra en beräkning av något slag. Eleverna uppfattar att det finns ett bestämt tal eller en bestämd siffra bakom bokstaven. Om man kan lista ut talet eller siffran genom att exempelvis gissa eller uppskatta så kan man lösa uppgiften som eleverna uppfattar anges i uttrycket. Vidare uppfattar eleverna att $x$ är ett okänt tal. Kategorin exemplifieras nedan med tre excerpter. I excerpt 1 ges exempel på att eleverna ser stavarna som representationer av ett visst antal som ska adderas. Detta synliggörs när eleverna pekar och räknar de enskilda små Cuisenairestavarna, en efter en, i en konkret beräkning. Den ena stapeln består av fem röda stavar och bredvid ligger en orange stav som motsvarar samma längd som de röda stavarna tillsammans. I excerpt 2 ger eleverna uttryck för att variabeln $x$ är en faktor i en multiplikation och menar att $x$ inte kan vara ett multiplikationstecken. I excerpt 3 exemplifieras att eleverna antar att en siffra gömmer sig bakom $x$. Således skiljer de mellan ett tal man ska räkna ut och en dold siffra.

\section{Excerpt 1 (intervjufråga 1)}

\begin{tabular}{|c|c|}
\hline Amir & "Kanske $5+5$ är lika med 10?" \\
\hline Intervjuare & "Hur tänker du när du säger 5 + 5 är lika med 10?" \\
\hline Amir & $\begin{array}{l}\text { "Att det här [pekar på de fem fysiska stavarna som är lika som på bilden (se Figur 2)] } \\
\text { är } 5 \text { som är uppdelade. Den här [pekar på den långa staven] är inte uppdelad i } 5 \text {, } \\
\text { men den är ändå lika lång som de här [pekar på de fem stavarna], så då skulle man } \\
\text { dela upp den här." [drar som små streck med fingret på den långa staven] }\end{array}$ \\
\hline Intervjuare & $\begin{array}{l}\text { "Så då är de tillsammans lika långa [pekar på de fem stavarna] som den?" [pekar på den } \\
\text { ensamma staven] }\end{array}$ \\
\hline Amir & "Ja." \\
\hline
\end{tabular}

Excerpt 2 (intervjufråga 1)

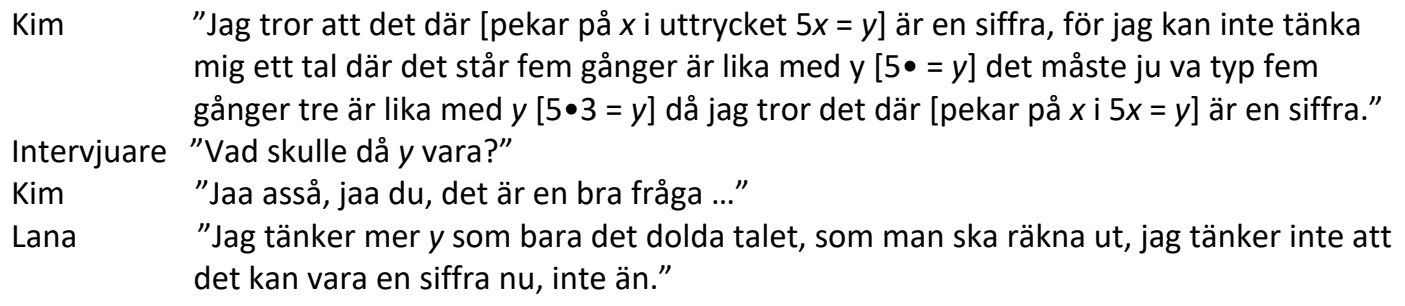
mig ett tal där det står fem gånger är lika med y $[5 \bullet=y]$ det måste ju va typ fem gånger tre är lika med $y[5 \bullet 3=y]$ då jag tror det där [pekar på x i $5 x=y$ ] är en siffra." Intervjuare "Vad skulle då y vara?" det kan vara en siffra nu, inte än." 
Excerpt 3 (intervjufråga 1)

Kim: Då så tänkte jag att det kanske, om det är nånting där bakom [pekar på x i uttrycket $5 x=y]$... så tänkte jag om det var typ femtiotvå (52), då skulle det vara en mer här [pekar på $y \mathrm{i}$ uttrycket $5 x=y$ ] som så att det blev femtiotre (53) här [pekar på $y \mathrm{i}$ uttrycket $5 x=y$ ], jag är jättedålig på att förklara /.../ jag tänkte det kan vara en dold siffra där bakom."

(åk 4)

\subsubsection{Kategori 2: ... något som beskriver en relation mellan komponenter}

Uppfattningar som utgör denna kategori indikerar ett erfarande av likhetstecknets betydelse eller funktion sett till det som finns på vardera sida om likhetstecknet. Eleverna uppfattar och tar med andra ord fasta på den relation som symboliseras av likhetstecknet, som till exempel i uttrycket $5 x=y$. De erfar alltså själva likhetstecknets betydelse i uttrycket $5 x=y$ och att $x$ och $y$ är variabler men inte att variablerna är representationer för något. Den siffra som finns i uttrycket anger bara hur många det är av något och om variabeln inte har någon siffra så är det bara en. En förståelse för relationen mellan delar och helheter inom uttrycket finns inbyggt i resonemanget. I excerpt 4 och 5 ger eleverna uttryck för att de är medvetna om att vilka symboler som väljs inte har någon betydelse och att till exempel $5 x=y$ uttrycker samma relation som $5 c=z$. Detta kan då också förstås som att det är egalt vilken symbol som används för att beteckna en variabel i ett givet uttryck.

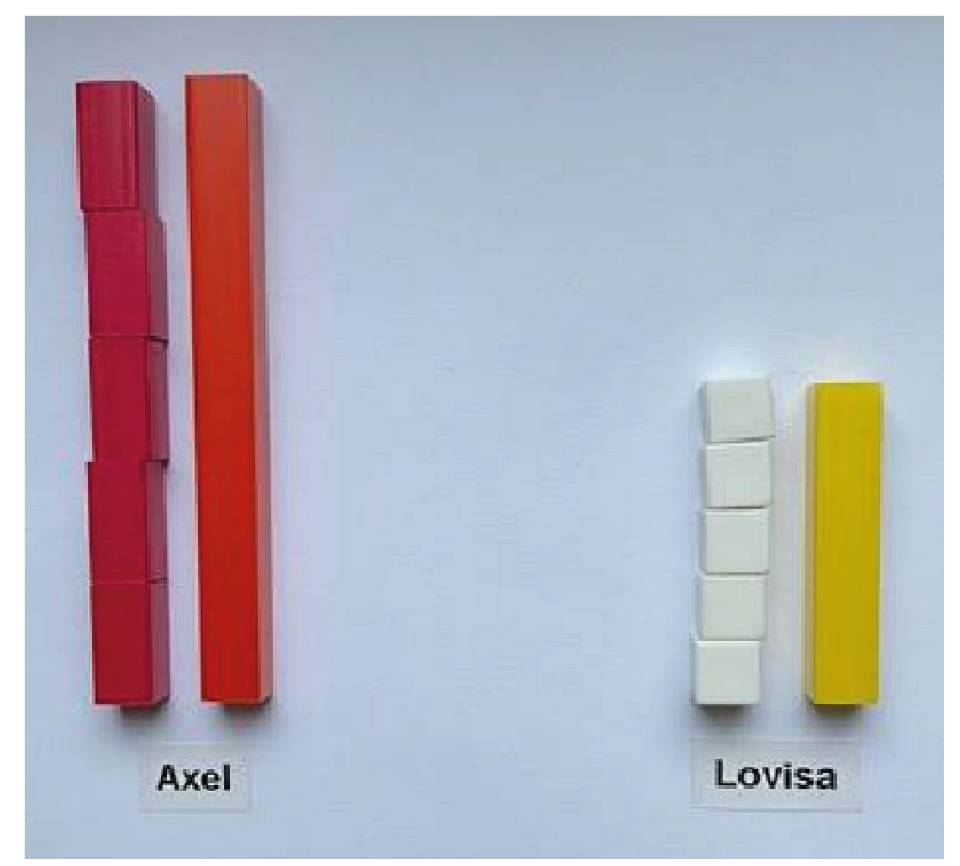

Figur 6. Axels och Lovisas stavkonstruktioner i relation till uttrycket $5 \mathrm{x}=\mathrm{y}$. 


\section{Excerpt 4 (intervjufråga 2)}

Intervjuare " $5 x$ är lika med $y$ [relaterar till det skrivna uttrycket $5 x=y$ på en bild framför dem]. Axel han la det så här och Lovisa la det så här [visar bilder på Axels och Lovisas stavkonstruktioner och lägger ut stavarna]. Hur kan de ha tänkt?"

/.../

Theo "Det står ju fem $x$ då blir det fem sådana." [pekar på bilden med Axels stavkonstruktion]

Rebecca "Ja, 1, 2, 3, 4, 5." [räknar de små röda stavarna]

Theo "Och så en $y . "$ " [pekar på den långa orange staven]

Rebecca "Ja."

Intervjuare "Så de tänkte att $5 x$ är lika med $y$ ?" [pekar på bilden på stavarna för att visa]

Theo "Ja."

Intervjuare "Sen var det en annan kille. Han fick det här [visar bilden på Axels stavkonstruktion], men han skrev inte $5 x=y$ utan han skrev $5 c=z$. Hur kan han ha tänkt?"

Rebecca "1, 2, 3, 4, 5." [pekar och skrattar]

Intervjuare "Vad tänkte du Rebecca?"

Rebecca "Att det är bara samma sak [som $5 x=y] . "$

(förskoleklass)

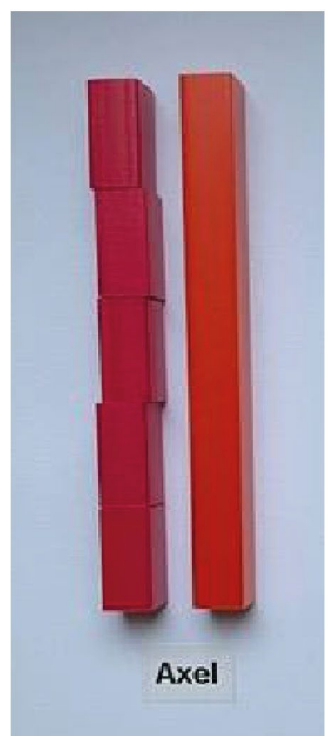

Figur 7. Axels stavkonstruktion i relation till uttrycket $5 x=y$ som Pelle uttryckte som $5 c=z$.

\section{Excerpt 5 (intervjufråga 3)}

Intervjuare "Så här skrev Pelle i den klassen [skriver uttrycket $5 c=z$ på en whiteboard]. Fem $c$ är lika med z." [Petra läser med i delar av uttrycket]

Olga "Va?!"

Intervjuare "Hur kan Pelle ha tänkte när han gjorde det?"

Olga "Femman kanske är de här fortfarande." [lägger handen på de fem röda stavarna]

Petra "Det tror jag, ja. För det är fem klossar. Då har vi det."

Olga "Men $c$ och $z$, är ju lite som $x$ och $y$ [pekar på $x$ och $y$ i uttrycket], $c$ och $z$." [pekar mot $c$ och $z$ i uttrycket]

Petra "Ja." [samtidigt som Olga] /.../

Olga "Fast, det står ju fem på båda." [pekar på båda femmorna i uttrycken]

Petra "Amen, det är ju det." [håller på båda femmorna]

Olga [ohörbart] "Tagit olika bokstäver typ."

Petra "De har använt olika bokstäver."

Olga "Fast det kan ju."/

Intervjuare /"Kan man göra det?" 
Olga "Jaa."

Petra "Men de kanske bara vill använda olika uttryck."

\subsubsection{Kategori 3: ... något som representerar en situation}

I denna kategori erfar eleverna att olika komponenter i ett algebraiskt uttryck bär på information som kan kopplas till en situation bortom själva uttrycket. En situation kan vara ett samband men också ett problem som kan modelleras med ett uttryck exempelvis $5^{x}=y .{ }^{8}$ Eleverna ser således att en konkret situation kan representeras av ett eller flera abstrakta algebraiska uttryck. Exempelvis uppfattar eleverna att en av de fiktiva eleverna har lagt sin stavkonstruktion kan exemplifieras som en situation som kan beskrivas med uttrycket $5 x=y$ och att $5 c=z$ kan representera en annan men även samma situation, men att en viss variabel måste representeras av samma symbol varje gång den förekommer.

\section{Excerpt 6 (intervjufråga 3 och 4)}

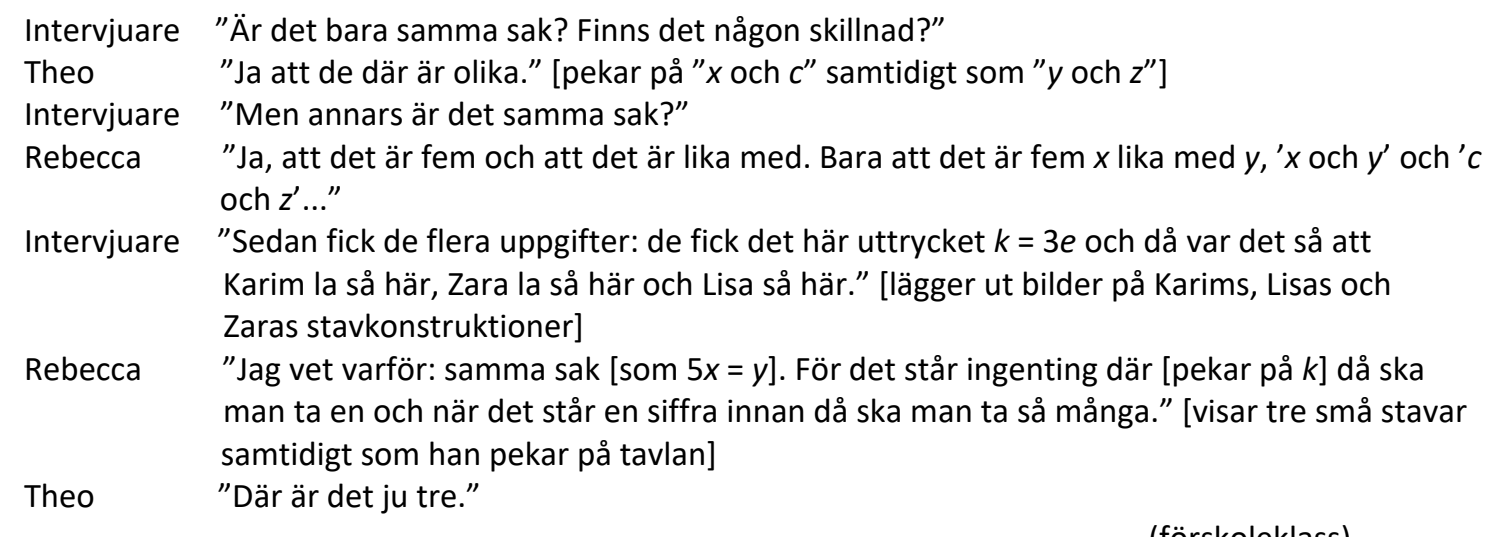

Excerpt 7 (intervjufråga 3)

\begin{tabular}{|c|c|}
\hline Fahime & "e?, men de här tre måste vara samma då." [pekar på Lisas olika långa stavar] \\
\hline Intervjuare & "Så du tänker att det inte stämmer?" \\
\hline Fahime & "Nej, [skakar på huvudet], för att tre e är lika med k, men det måste vara tre av samma." \\
\hline Intervjuare & $\begin{array}{l}\text { "Så den [Karims stavkonstruktion] stämmer, vad säger du, håller du med?" [vänder sig } \\
\text { till Ester] }\end{array}$ \\
\hline Ester & "Ja, de här tre ska vara lika." [pekar på Lisas olika långa stavar] \\
\hline
\end{tabular}

(åk 1)

\footnotetext{
${ }^{8}$ I svenska läromedel i matematik för yngre åldrar beskrivs ofta konkreta vardagshändelser i form av till exempel räknesagor till vilka ett uttryck kan kopplas (se t.ex. läromedelsserierna Favorit matematik 2A (Ristola et al., 2012) och Matte Direkt Safari 2A (Falck et al., 2009)). I elevintervjuerna har möjliga situationer representerats med olika konstruktioner med Cuisenairestavar.
} 
Excerpt 8 (intervjufråga 4)

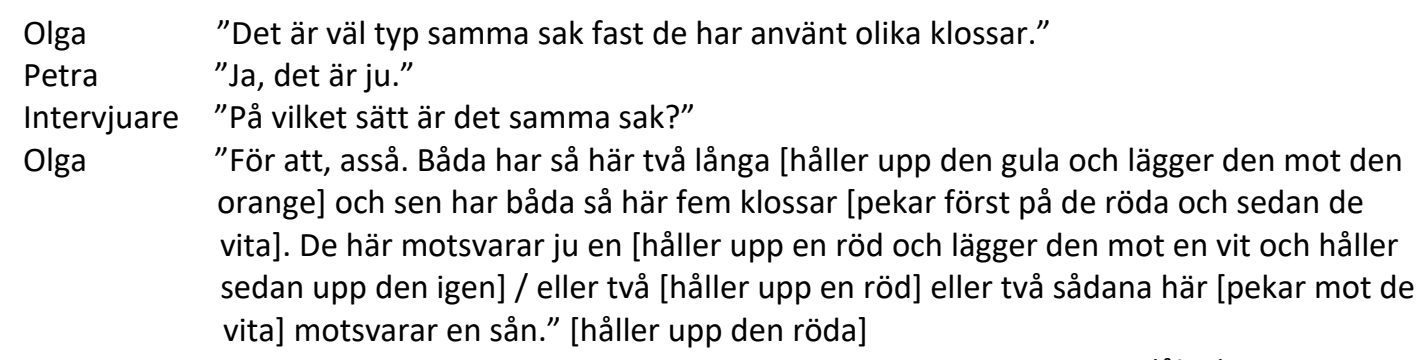

Sammanfattningsvis kan sägas att i kategorin "något som kan och bör räknas ut" uppfattar eleverna att ett algebraiskt uttryck innebär en uppmaning om att ta reda på vilka möjliga värden de obekanta talen representerar. Kategorin "något som beskriver en relation mellan komponenter" handlar om att eleverna erfar likheter och likhetstecknet inom ett uttryck. I den tredje kategorin, "något som representerar en situation”, erfar eleverna att samma uttryck kan representera olika situationer eller att samma situation kan representeras av olika uttryck men även att eleverna erfar strukturella likheter mellan olika uttryck.

\subsection{Vad elever behöver urskilja}

Genom att analysera uppfattningarna i relation till varandra har tre kritiska aspekter som skiljer de olika uppfattningarna åt identifierats. Tentativt indikerar dessa vad elever behöver urskilja för att utveckla ett mera kvalificerat kunnande av vad som kan vara det matematiska i algebraiska uttryck. De identifierade kritiska aspekterna i relation till kategorierna sammanfattas i Figur 8. De två kritiska aspekterna som skiljer kategori två från kategori tre är icke-hierarkiska men behöver båda urskiljas för att utveckla uppfattningar motsvarande kategori tre. Dessa urskiljs oberoende av varandra och inte nödvändigtvis i en specifik ordning. 

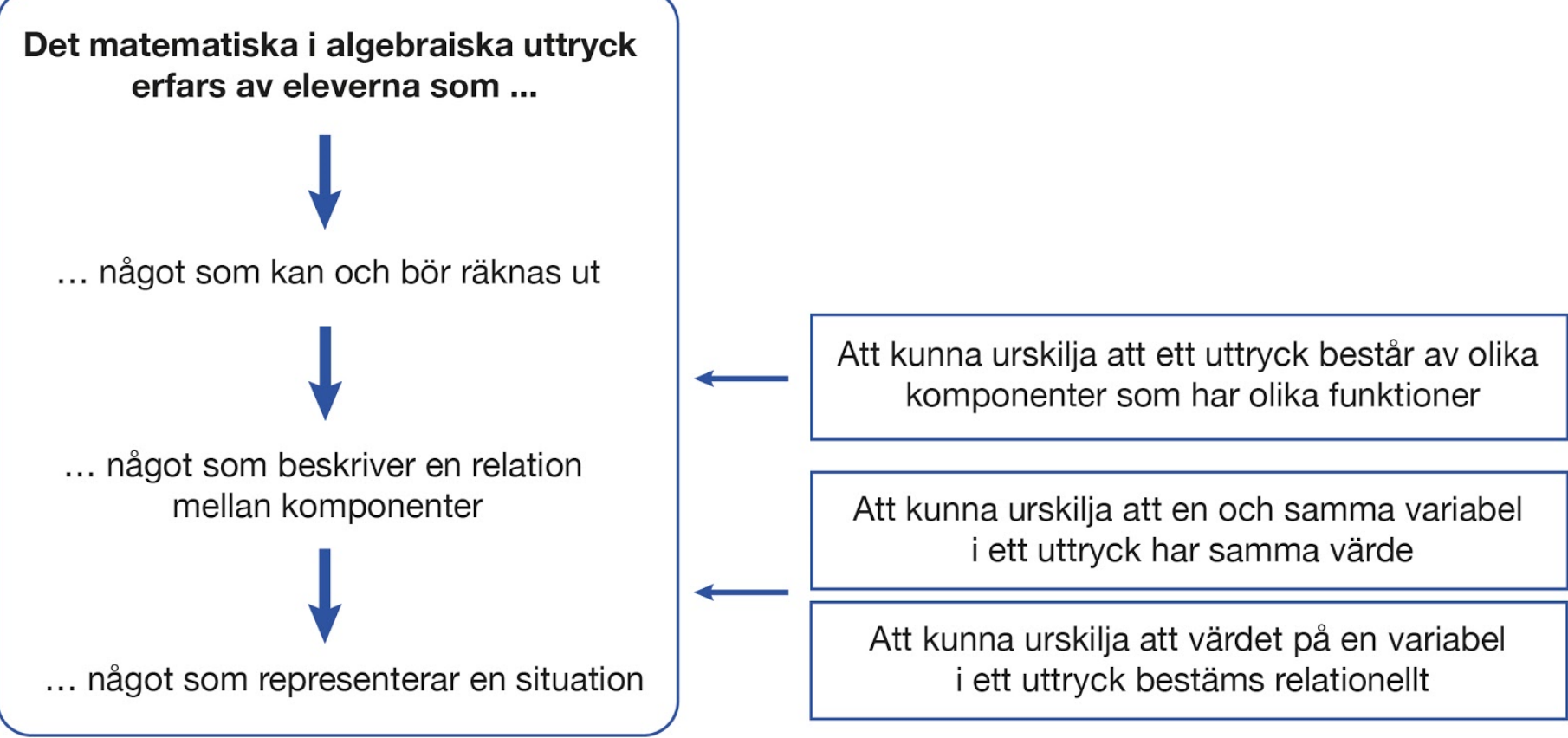

Figur 8. Schematisk bild över identifierade kategorier (till vänster) och kritiska aspekter (till höger).

I den första kategorin "något som kan och bör räknas ut" visar utsagorna att eleverna ännu inte har urskilt att exempelvis bokstäverna a, b och c i uttrycket $a+b$ $=c$ är variabler, att + är en operator och att $=$ uttrycker en relation.

Av utsagorna som bildar den andra kategorin, "något som beskriver en relation mellan komponenter", kan man se att eleverna urskiljer att uttrycken innefattar de matematiska komponenterna även om de inte kan benämna dem. Eleverna är således inte bekanta med terminologin som till exempel variabler och komponenter. Utsagorna visar också att eleverna urskiljer strukturen inom ett uttryck och att symbolerna $x$ och $y$ i $5 x=y$ är variabler, det vill säga att deras värden kan variera. De erfar också att det finns ett samband mellan $x$ och $y$ och således att variablerna inte är oberoende av varandra, samt att det inte spelar någon roll vilka beteckningar för variablerna man väljer. Istället för $x$ och $y$ kan man välja exempelvis $c$ och $z$. Relationen uttrycks då $5 c=z$. Uppfattningen innefattar, som tidigare nämnts, å den ena sidan ett samband mellan två variabler, och å den andra att en och samma relation kan uttryckas på flera olika sätt, till exempel genom att variabelbeteckningarna varieras mellan uttryck.

Utsagorna i den tredje kategorin "något som representerar en situation" visar att eleverna har urskilt att samma uttryck kan representera olika situationer eller att samma situation kan representeras av olika uttryck. Exempelvis kan en situation som beskrivs av ett uttryck $a=b+c$ även beskrivas $x=y+z$ om man byter beteckningar 
på variablerna. Den kan också beskrivas $c=a-b$ eller $b=a-c$. Utsagorna som bildar kategori tre visar även att eleverna urskiljer den strukturella likheten mellan $5 x=y$ och $k=3 e$, det vill säga att ett visst antal av något (t.ex. $x$ eller $e$ ) är lika med något annat ( $y$ respektive $k$ ). Urskiljandet innefattar att antalet och/eller symboler kan vara olika utan att strukturen ändras. För att utveckla en uppfattning som motsvaras av kategori tre (se speciellt excerpt 6 och 7) behöver eleverna urskilja både att en och samma variabel har samma värde och att värdet på en variabel bestäms relationellt.

\section{Diskussion}

I det följande diskuterar vi resultatet i relation till syftet och forskningsfrågorna: Vilka kvalitativt skilda sätt att erfara algebraiska uttryck kan urskiljas? Vilka aspekter behöver eleverna erfara för att de ska ges möjlighet att kvalificera sina uppfattningar om algebraiska uttryck?

\subsection{Kvalitativt skilda erfaranden av det matematiska i algebraiska uttryck}

Som redovisats i resultatet ovan framträdde tre hierarkiskt ordnade kategorier: 1) "något som kan och bör räknas ut", 2) "något som beskriver en relation mellan komponenter" och 3) "något som representerar en situation". Liksom i ett flertal av de studier som kan kopplas samman med ett utforskande av elevers uppfattningar av algebraiska uttryck identifierade vi, innan preciseringen av fenomenet, två uppfattningar som inte kan ses som matematiskt relevanta (jfr t.ex. MacGregor \& Stacey, 1997; Stacey \& MacGregor, 1997). Då vårt fokus i projektet var att designa en undervisning som skulle öppna upp för en matematisk relevant förståelse av algebraiska uttryck preciserades fenomenet till elevers uppfattningar av det matematiska i algebraiska uttryck (Eriksson et al., 2019; Tambour, 2019).

I den hierarkiska ordningen som presenterats i utfallsrummet beskrivs den enklaste uppfattningen en uppmaning till att göra någon slags beräkning. Denna typ av uppfattning återfinns i ett flertal av de studier som ingår i forskningsöversikten ovan (Kieran, 1981; Küchemann, 1981). De två andra kategorierna i utfallsrummet är det inte lika lätt att finna en motsvarighet till i den tidigare forskningen. Exempelvis kan de sex kategorier som Küchemann presenterat inte enkelt relateras till vårt utfallsrum. Även om kategori 1 (något som kan och bör räknas ut) mycket väl kan jämföras med den kategori som Küchemann benämner som bokstaven används som ett specifikt okänt tal kan hans två följande kategorier bokstaven används som ett 
godtyckligt tal och bokstaven används som en variabel inte lika enkelt jämföras med de två mer kvalificerade uppfattningarna i vårt utfallsrum. Snarare går det att argumentera för att Küchemanns två sista kategorier utgör en förutsättning för de två mer kvalificerade av våra kategorier. En skillnad kan noteras är typen av uppgifter eleverna i dessa två studier fått möta jämfört med de uppgifter de intervjuade eleverna fick möta. Det framstår som att flera av de uppgifter Küchemann använder indikerar möjliga beräkningar i form av ekvationer, medan våra elever fått möta vad som kan beskrivas som "rena" algebraiska ekvationer eller uttryck.

Med referens till Piaget är det inte ovanligt att lärare har en förväntan på att de yngsta eleverna inte ska kunna visa tecken på en mera utvecklad algebraisk förståelse (se t.ex. Wagner, 1983). Men i vår fenomenografiska analys kan vi inte se en sådan skillnad relaterat till deltagarnas ålder, utan exempel på de tre uppfattningarna som slutligen urskildes fanns representerade hos elever som intervjuades i såväl förskoleklass som i årskurs 1 och i årskurs 4. Av analysen framträder att redan i förskoleklass kan elever föra ett resonemang om algebraiska uttryck som kan kategoriseras som mera utvecklat. Med hänvisning till exempelvis Attorps (2006) studie kan även lärare ha en uppfattning som enligt Wagners resonemang endast borde återfinnas hos de yngsta. Det går således inte att ha en förväntan om att de yngsta elevernas utsagor endast skulle återfinnas i den minst kvalificerade kategorin

Med det preciserade fenomenet fick vi således fram tre kategorier av uppfattningar vilka gav tre kritiska aspekter som också kunde ge oss vägledning till designen av de kommande forskningslektionerna i forskningsprojektet.

\subsection{Kritiska aspekter för ett mer differentierat urskiljande av innebörden av algebraiska uttryck}

De kritiska aspekter som ger eleverna möjlighet att kvalificera sina uppfattningar för att utveckla ett mer komplext kunnande av algebraiska uttryck är 1) att kunna urskilja att ett uttryck består av olika komponenter som har olika funktioner, 2) att kunna urskilja att en och samma variabel i ett uttryck har samma värde och 3) att kunna urskilja att värdet på en variabel i ett uttryck bestäms relationellt. Det finns, som nämnts, en idé med kritiska aspekter att det är sådana aspekter som den specifika elevgruppen behöver urskilja för att utveckla mer kvalificerade uppfattningar (Pang \& Ki, 2016; Runesson, 2011, 2017). Det innebär således att vid planering av en kommande lektion eller lektionsserie behöver undervisningen designas så att de kritiska aspekterna blir möjliga för eleverna att urskilja (Marton, 2015; Runesson, 
2017). Det kan med dessa antaganden framstå som möjligen oväntat att elever i förskoleklass, årskurs 1 och elever i årskurs fyra skulle behöva lära sig samma sak. Dock har ett antal studier på senare år visat att när elever med stor åldersskillnad och därmed olika erfarenheter av matematik möter ett innehåll som är helt nytt för dem så uppvisar eleverna, på gruppnivå, behov av likartat undervisningsinnehåll (Kullberg, 2012; Runesson, 2017; Tuominen et al., 2018).

Enligt kursplanen lyfts algebra som innehåll redan från de första årskurserna, men hur det ska behandlas sägs inget om (Hemmi et al., 2020). Matematikundervisningen i Sverige karakteriseras vanligen som läromedelsstyrd och studier visar att elever sällan möter komplexa uppgifter som exempelvis inbegriper generella, grundläggande och teoretiska samband (Bråting et al., 2019; Hemmi et al., 2019). I det internationella forskningsfältet lyfts vikten av en tidig introduktion till algebra (Blanton et al., 2015; Davydov, 2008; Kaput, 2008; Kieran et al., 2016; Venenciano \& Dougherty, 2014). Forskningsprojektet som den här artikeln har hämtat data ifrån utgör ett exempel på ett utforskande av hur algebra kan introduceras redan för de yngsta eleverna (Eriksson et al., 2019). Med en sådan ambition behöver undervisningen designas medvetet för att skapa förutsättningar för utveckling av elevers algebraiska tänkande och att detta kan utifrån våra data ske tidigt (Blanton et al., 2015; Eriksson \& Jansson, 2017; Eriksson et al., 2019; Kieran, 2004, 2011). Att ha kunskaper om vad olika elevgrupper uppfattar algebraiska fenomen som och att på basis av det kunna identifiera möjliga kritiska aspekter ger läraren förutsättningar för att designa en meningsfull undervisning.

\section{Tack}

Projektet som artikeln bygger på har finansierats av Skolforskningsinstitutet (diarienummer 2016/151). Ett stort tack till de övriga kollegorna i forskargruppen. Vi vill också tacka lärarna som medverkade i planeringen, förberedelserna inför intervjuerna, samt analysarbetet efter de genomförda intervjuerna: Carina Andersson, Lars Andersson, Jenny Björklund, Helena Buchberger, Hiba Mikhail, Eva-Lena Nielsen, Birgitta Nilsson och Boel Staffansson. Vidare riktar vi ett stort tack till eleverna som medverkade i intervjuerna. 


\section{Referenser}

Adawi, T., Berglund, A., Ingerman, Å., \& Booth, S. (2001). On context in phenomenographic research on understanding heat and temperature. In The 9th EARLI conference, Fribourg, August 2001, Fribourg, Switzerland.

Attorps, I. (2006). Mathematics teachers' conceptions about equations. [Doktorsavhandling, Helsingfors universitet]. bit.ly/2Xk8gPl

Blanton, M. L., Brizuela, B. M., Stephens, A., Knuth, E., Isler, I., Murphy Gardiner, A., Stroud, R., Fonger, N., \& Stylianou, D. (2018). Implementing a framework for early algebra. I C. Kieran (Red.), Teaching and learning algebraic thinking with 5- to 12-year-olds (s. 27-49). Springer. https://doi.org/10.1007/978-3-319-68351-5_2

Blanton, M., Stephens, A., Knuth, E., Murphy Gardiner, A., Isler, I., \& Kim, J-S. (2015). The development of children's algebraic thinking: The impact of a comprehensive early algebra intervention in third grade. Journal for Research in Mathematics Education, 46(1), 39-87. https://www.jstor.org/stable/10.5951/jresematheduc.46.1.0039

Bråting, K., Hemmi, K., \& Madej, L. (2018). Teoretiska och praktiska perspektiv på generaliserad aritmetik. I J. Häggström, Y. Liljekvist, J. Bergman Ärlebäck, M. Fahlgren, \& O. Olande (Red.), Perspectives on professional development of mathematics teachers. Proceedings of $M A D I F 11$ (s. 27-36). NCM \& SMDF.

Bråting, K., Madej, L., \& Hemmi, K. (2019). Development of algebraic thinking: opportunities offered by the Swedish curriculum and elementary mathematics textbooks. Nordic Studies in Mathematics Education, 24(1), 27-49. http://ncm.gu.se/nomad-sokresultatvy?brodtext=24_1_brating

Cai, J., \& Knuth, E. (Red.). (2011). Early algebraization: A global dialogue from multiple perspectives. Springer. https://doi.org/10.1007/978-3-642-17735-4

Carpenter, T. P., Franke, M. L., \& Levi, L. (2003). Thinking mathematically: Integrating arithmetic and algebra in elementary school. Heinemann.

Davydov, V. V. (1975). The psychological characteristics of the "prenumerical" period of mathematics instruction. I L. Steffe (Red.), Children's capacity for learning mathematics. Soviet studies in psychology of learning and teaching mathematics, Volume 7 (s. 109205). School mathematics study group. (Originalutgàvan publicerad 1966).

Davydov, V. V. (1990). Types of generalization in instruction: Logical and psychological problems in the structuring of school curricula. Soviet Studies in Mathematics Education, 2, 2-222. NCTM. (Originalutgåvan publicerad 1972).

Davydov, V. V. (2008). Problems of developmental instruction: a theoretical and experimental psychological study. Nova Science Publishers, Inc. (Originalutgåvan publicerad 1986).

Eriksson, H. (2015). Rationella tal som tal. Algebraiska symboler och generella modeller som medierande redskap. [Licentiatuppsats, Stockholms universitet].

http://urn.kb.se/resolve?urn=urn:nbn:se:su:diva-129269

Eriksson, I. (1999). Lärares pedagogiska handlingar: En studie av lärares uppfattningar av att vara pedagogisk i klassrumsarbetet. [Doktorsavhandling, Uppsala universitet]. bit.ly/2J1Ry3v

Eriksson, I., \& Jansson, A. (2017). Designing algebraic tasks for 7-year-old students - a pilot project inspired by Davydov's learning activity. International Journal for Mathematics Teaching and Learning, 18(2), 257-272.

https://www.cimt.org.uk/ijmtl/index.php/IJMTL/issue/view/6

Eriksson, I., Wettergren, S., Fred, J., Nordin, A.-K., Nyman, M., \& Tambour, T. (2019). Materialisering av algebraiska uttryck i helklassdiskussioner med lärandemodeller som 
medierande redskap i årskurs 1 och 5. Nordic Studies in Mathematics Education, 24(3-4), 86-106. http://ncm.gu.se/nomad-sokresultat-vy?brodtext=24_34_081106_eriksson

Falck, P., Elofsdotter Meijer, S., \& Picetti, M. (2009). Matte Direkt Safari 2 A. (1. uppl.) Bonnier utbildning. https://www.sanomautbildning.se/sv/produkter/matte-direkt-safari-upplaga2-S3174022

Frieman, V., \& Lee, L. (2004). Tracking primary students' understanding of the equality sign. I M. Johnsen Hines \& A. B. Fuglestad (Red.), Proceedings of the 28th Conference of the International Group for the Psychology of Mathematics Education (Vol. 2, s. 415-422). IGPME.

Gravemeijer, K. (2002). Preamble: From models to modeling. I K. Gravemeijer, R. Lehrer, B. van Oers \& L. Verschaffel (Red.), Symbolizing, modeling and tool use in mathematics education (s. 7-22). Springer. https://doi.org/10.1007/978-94-017-3194-2_2

Greer, B. (2008). Algebra for all? The Mathematics Enthusiast, 5(2/3), 423-428. https://scholarworks.umt.edu/tme/vol5/iss2/23

Hemmi, K., Bråting, K., \& Lepik, M. (2020). Curricular approaches to algebra in Estonia, Finland and Sweden - a comparative study. Mathematical Thinking and Learning, 1-23. https://doi.org/10.1080/10986065.2020.1740857

Hemmi, K., Lepik, L., Madej, L., Bråting, K., \& Smedlund, J. (2019). Introduction to early algebra in Estonia, Finland and Sweden - Some distinctive features identified in textbooks for Grades 1-3. I U. T. Jankvist, M. van den Heuvel-Panhuizen, \& M. Veldhuis (Red.), Proceedings of the Eleventh Congress of the European Society for Research in Mathematics Education (CERME11, February 6-1O, 2019). Freudenthal Group \& Freudenthal Institute, Utrecht University and ERME.

Ingerman, A., Linder, C., \& Marshall, D. (2009). The learners' experience of variation: Following students' threads of learning physics in computer simulation sessions. Instructional Science, 37(3), 273-292. https://doi.org/10.1007/s11251-007-9044-3

Jaidin, J. H. (2018). Scenario-based interview: An alternative approach to interviewing children? Asia-Pacific Journal of Research in Early Childhood Education, 12(1), 23-37. https:/7doi.org/10.17206/apjrece.2017.12.1.23

James, G., \& James R. C. (1976). Mathematics dictionary. van Nostrand Reinhold.

Jägerskog, A.-S. (2020). Making Possible by Making Visible: Learning through Visual Representations in Social Science. [Doktorsavhandling, Stockholms universitet]. http://www.diva-portal.org/smash/record.jsf?pid=diva2\%3A1392534\&dswid=634

Kaput, J. J. (1999). Teaching and learning a new algebra. I E. Fennema \& T. A. Romberg (Red.), Mathematics classrooms that promote understanding (s. 133-155). Routledge. https://doi.org/10.4324/9781410602619

Kaput, J. J. (2008). What is algebra? What is algebraic reasoning? I J. J. Kaput, D. W. Carraher \& M. Blanton (Red.), Algebra in the early grades (s. 5-17). Routledge. https://doiorg.ezp.sub.su.se/10.4324/9781315097435

Kaput, J. J., Carraher, D., \& Blanton, M. (2008). Algebra in the early grades. Routledge. https://doi.org/10.4324/9781315097435

Kieran, C. (1981). Concepts associated with the equality symbol. Educational Studies in Mathematics, 12, 317-326. https://doi.org/10.1007/BFo0311062

Kieran, C. (2004). Algebraic thinking in the early grades. What is it? The Mathematics Educator, 8(1), 139-151. https://gpc-maths.org/data/documents/kieran2004.pdf

Kieran, C. (2006). Research on the learning and teaching of algebra: A broadening of sources of meaning. I A. Gutiérrez \& P. Boero (Red.), Handbook of research on the psychology of mathematics education: past, present and future (s. 11-49). Sense Publishers. 
Kieran, C. (2011). Overall commentary on early algebraization: Perspectives for research and teaching. I J. Cai \& E. Knuth (Red.), Early algebraization: A global dialogue from multiple perspectives (s. 579-593). Springer. https://doi.org/10.1007/978-3-642-17735-4_29

Kieran, C. (2018). Introduction. I C. Kieran (Red.), Teaching and learning algebraic thinking with 5- to 12-year-olds. ICME-13 Monographs (s. ix-xiii). Springer.

Kieran, C., Pang, J., Schifter, D., \& Ng, S. F. (2016). Early algebra research into its nature, its learning, its teaching. Springer. https://doi.org/10.1007/978-3-319-32258-2

Kilhamn, C., \& Röj-Lindberg, A.-S. (2019). Algebra teachers' questions and quandaries - Swedish and Finnish algebra teachers discussing practice. Nordic Studies in Mathematics Education, 24(3-4), 153-171. http://ncm.gu.se/nomad-sokresultatvy?brodtext=24_34_kilhamn

Kiselman, C., \& Mouwitz, L. (2008). Matematiktermer för skolan. NCM.

Knuth, E. J., Alibali, M. W., McNeil, N. M., Weinberg, A., \& Stephens, A. C. (2005). Middle school students' understanding of core algebraic concepts: Equivalence \& Variable. Zentralblatt für Didaktik der Mathematik, 37(1), 68-76. https://doi.org/10.1007/BF02655899

Krutetskii, V. D. (1976). The psychology of mathematical abilities in school children. The University of Chicago Press.

Kullberg, A. (2012). Can findings from learning studies be shared by others? International Journal for Lesson and Learning Studies, 1(3), 232-244.

https://doi.org/10.1108/20468251211256438

Kullberg, A, Runesson Kempe, U., \& Marton, F. (2017). What is made possible to learn when using the variation theory of learning in teaching mathematics?. ZDM Mathematics Education, 49(4), 559-569. https://doi.org/10.1007/s11858-017-0858-4

Küchemann, D. (1981). Algebra. I K. Hart (Red.), Children's understanding of mathematics (Vol. 11-16, s. 102-119). Murray.

Küchemann, D. (2019). Cuisenaire Rods and Symbolic Algebra. Mathematics Teaching, 265, 3437.

Linell, P. (1994). Transkription av tal och samtal: teori och praktik. Linköping universitet, Tema kommunikation.

Lins, R., \& Kaput, J. J. (2004). The early development of algebraic reasoning: The current state of the field. I K. Stacey, H. Chick \& M. Kendal (Red.), The future of the teaching and learning of algebra: The 12th ICMI study (s. 45-70). Springer. https://doi.org/10.1007/1-40208131-6_4

MacGregor, M., \& Stacey, K. (1997). Students' understanding of algebraic notation: 11-15. Educational Studies in Mathematics, 33(1), 1-19.

https://doi.org/10.1023/A:1002970913563

Marton, F. (1981). Phenomenography - describing conceptions of the world around us. International Science, 1O(2), 177-200. https://doi.org/10.1007/BF00132516

Marton, F. (2015). Necessary conditions of learning. Routledge.

Mason, J. (2008). Making use of children's powers to produce algebraic thinking. I J. J. Kaput, D. Carraher \& M. Blanton (Red.), Algebra in the early grades (s. 57-94). Routledge. https://doi-org.ezp.sub.su.se/10.4324/9781315097435

Mason, J. (2018). How early is too early for thinking algebraically? I C. Kieran (Red.), Teaching and learning algebraic thinking with 5- to 12-year-olds. ICME-13 Monographs (s. 329350). Springer. https://doi.org/10.1007/978-3-319-68351-5_14

Morris, A., \& Sloutsky, V. (1995). Development of algebraic reasoning in children and adolescents: a cross-cultural and cross-curricular perspective. Paper presented at the Annual Meeting of the North American Chapter of the International Group for the 
Psychology of Mathematics Education (17th PME-NA, Columbus, OH, October 21-24, 1995).

Nordin, A.-K., \& Boistrup, L. B. (2018). A framework for identifying mathematical arguments as supported claims created in day-to-day classroom interactions. Journal of Mathematical Behavior, 51, 15-27. https://doi.org/10.1016/j.jmathb.2018.06.005

Olteanu, C. (2007). "Vad skulle x kunna vara?” Andragradsekvation och andragradsfunktion som objekt för lärande. [Doktorsavhandling, Umeå universitet]. http://www.divaportal.org/smash/record.jsf?pid=diva2\%3A208216\&dswid=-4687

Olteanu, C. (2014). Matematiskt resonemang och kritiska aspekter. Skolverket. bit.ly/3ldqwU9

Pang, M. F. (2003). Two faces of variation: On continuity in the phenomenographic movement. Scandinavian Journal of Educational Research, 47(2), 145-156. https://doi.org/10.1080/00313830308612

Pang, M. F., \& Ki, W. W. (2016). Revisiting the idea of "critical aspects". Scandinavian Journal of Educational Research, 6o(3), 323-336. https://doi.org/10.1080/00313831.2015.1119724

Radford, L. (2015). Early algebraic thinking: Epistemological, semiotic, and developmental issues. I S. J. Cho (Red.), The Proceedings of the 12th International Congress on Mathematical Education (s. 209-227). Springer. https://doi.org/10.1007/978-3-319-12688-3_15

Riesbeck, E. (2008). På tal om matematik: matematiken, vardagen och den matematikdidaktiska diskursen. [Doktorsavhandling, Linköpings universitet]. http://liu.diva-portal.org/smash/record.jsf?pid=diva2\%3A17750\&dswid=-4740

Ristola, K., Tapaninaho, T., \& Vaaranniemi, L. (2012). Favorit matematik 2A. (1. uppl.) Studentlitteratur.

Ronda, E. R. (2009). Growth points in students' developing understanding of function in equation form. Mathematics Education Research Journal, 21(1), 31-53. https://doi.org/10.1007/BFO3217537

Runesson, U. (2011). Lärares kunskapsarbete - exemplet learning study. I Eklund, S. (Red.) Lärare som praktiker och forskare: om praxisnära forskning (s. 7-17). Stiftelsen SAF i samverkan med Lärarförbundet.

Runesson, U. (2017). Variationsteori som redskap för att analysera lärande och designa undervisning. I Carlgren, I. (Red.), Undervisningsutvecklande forskning. Exemplet learning study (s. 45-60). Gleerups.

Schmittau, J. (2004). Vygotskian theory and mathematics education: Resolving the conceptualprocedural dichotomy. European Journal of Psychology of Education, XIX(I), 19-43. https://doi-org.ezp.sub.su.se/10.1007/BF03173235

Schmittau, J. (2005). The development of algebraic thinking. A Vygotskian perspective. Zentralblatt für Didaktik der Mathematik, 37(1), 16-22. https://doiorg.ezp.sub.su.se/10.1007/bfo2655893

Schmittau, J., \& Morris, A. (2004). The development of algebra in the elementary mathematics curriculum of V. V. Davydov. The Mathematics Educator, 8(1), 60-87.

Sfard, A. \& Linchevski, L. (1994). The gains and the pitfalls of reification: The case of algebra. Educational Studies in Mathematics, 26(2/3), 191-228. https://doi.org/10.1007/BF01273663

Skolforskningsinstitutet. (17 november 2020). Finansierade forskningsprojekt 2016. https://www.skolfi.se/forskningsfinansiering/finansierade-forskningsprojekt-2016

Skolverket (2019). Läroplan för grundskolan, förskoleklassen och fritidshemmet 2011: reviderad 2019. Skolverket. 
Skolverket. (17 november 2020). Ändrade kursplaner - bättre arbetsverktyg för dig som lärare. Matematik. https://www.skolverket.se/om-oss/var-verksamhet/skolverkets-prioriteradeomraden/reviderade-kurs--och-amnesplaner/andrade-kursplaner-i-grundskolan

Stacey, K., \& Chick, H. (2004). Solving the problem with algebra. I K. Stacey, H. Chick \& M. Kendal (Red.), The future of the teaching and learning of algebra: The 12th ICMI study (s. 1-20). Springer. https://doi.org/10.1007/1-4020-8131-6_1

Stacey, K., \& MacGregor, M. (1997). Ideas about symbolism that students bring to algebra. The Mathematics Teacher, 9o(2), 110-113. http://www.jstor.org/stable/27970090

Stacey, K., \& MacGregor, M. (1999). Learning the algebraic method of solving problems. Journal of Mathematical Behavior, 18(2), 149-167. https://doi.org/10.1016/So7323123(99)00026-7

Stockholms universitet. (17 november 2020). Föra och följa algebraiska resonemang. Developing algebraic reasoning capability.

https://www.su.se/hsd/forskning/forskningsprojekt/formagan-att-fora-och-foljaalgebraiska-resonemang

Tambour, T. (2019). Tänka om matematik som utgångspunkt för att utveckla undervisningen i matematik - exemplet algebra och algebraisk struktur. I Y. Ståhle, M. Waermö \& V. Lindberg (Red.), Att utveckla forskningsbaserad undervisning: analyser, utmaningar och exempel (s. 157-175). Natur och Kultur.

Tuominen, J., Andersson, C., Björklund-Boistrup. L., \& Eriksson, I. (2018). Relate before calculate: Students' ways of experiencing relationships between quantities. Didactica Mathematicae, 4O, 5-33. http://yadda.icm.edu.pl/yadda/element/bwmeta1.element.ojs-doi10_14708_dm_v40io_6431

Undervisningsministeriet. (5 maj 2020). Läroplan för ämnet matematik. [Læseplan for faget matematik]. https://emu.dk/grundskole/matematik/laeseplan-og-vejledning

Usiskin, Z. (1988). Conceptions of school algebra and uses of variables. I A. F. Coxford \& A. P. Shulte (Red.), Ideas of algebra: K-12. 1988 Yearbook of the National Council of Teachers of Mathematics (s. 8-19). NCTM.

Utbildningsstyrelsen. (5 maj 2020). Grunderna för läroplanen för den grundläggande utbildningen 2014. https://www.oph.fi/sv/utbildning-och-examina/grundlaggandeutbildning/matematik-i-den-grundlaggande-utbildningen

Utdanningsdirektoratet. (5 maj 2020). Läroplan i matematik årskurs 1-10. [Læreplan i matematikk 1.-10. trinn]. https://www.udir.no/LK20/mato1-05

van Oers, B. (2001). Educational forms of initiation in mathematical culture. Educational Studies in Mathematics, 46(1-3), 59-85. https://doi.org/10.1023/A:1014031507535

Venenciano, L., \& Dougherty, B. (2014). Addressing priorities for elementary school mathematics. For the Learning of Mathematics, 34(1), 18-24. https://www.jstor.org/stable/43894872

Wagner, S. (1983). What are these things called variables? The Mathematics Teacher, 76(7), 474479. https://www.jstor.org/stable/27963648

Wahlström, R., Dahlgren, L. O., Tomson, G., Diwan, V. K., \& Beermann, B. (1997). Changing primary care doctors' conceptions: A qualitative approach to evaluating an intervention. Advances in Health Sciences Education, 2(3), 221-236. https://doi.org/10.1023/A:1009763521278

Wernberg, A. (2009). Lärandets objekt: Vad elever förväntas lära sig, vad görs möjligt för dem att lära och vad de faktiskt lär sig under lektionerna. [Doktorsavhandling, Umeå universitet]. bit.ly/339UngS

Österlind, E. (1998). Disciplinering via frihet: elevers planering av sitt eget arbete. [Doktorsavhandling, Uppsala universitet]. bit.ly/398PmlT 